\title{
Biofloc Technology (BFT): An Effective Tool for Remediation of Environmental Issues and Cost Effective Novel Technology in
}

\section{Aquaculture}

\author{
Das SK${ }^{*}$ and Mandal A² \\ 1West Bengal University of Animal and Fishery Sciences, West Bengal, India \\ ${ }^{2}$ Guru Angad Dev Veterinary and Animal Sciences University, Ludhiana, Punjab, India \\ *Corresponding author: SK Das, West Bengal University of Animal and Fishery \\ Sciences, West Bengal, India, Tel: Mob: 9433130947; Email: skdaswbuafs@gmail.com
}

Review Article

Volume 2 Issue 2

Received Date: March 22, 2018

Published Date: April 09, 2018

\begin{abstract}
The importance of biofloc technology in aquaculture as an effective bioremediation tool for environmental problems, means of poverty alleviation and meeting food security in the coming years is discussed. Biofloc technology (BFT) can be effective in replacing costly feed aquaculture with simultaneous environmental amelioration with no additional cost. Besides biofloc system became more economic as it operated under zero water exchange system thereby reducing cost of water exchange. BFT is known to prevent the accumulation of toxic nitrogen metabolites $\left(\mathrm{NH}_{3}\right.$, $\mathrm{NO}_{2}$, etc.) by stimulating and manipulating the carbon/nitrogen ratio $(\mathrm{C} / \mathrm{N})$ and converting these metabolites to microbial flocs. The presence of diverse group of bacteria especially, Bacillus sp. and Lactobacillus sp. indicate that biofloc can be considered as a source of potential probiotics besides acting as valuable protein inputs. BFT is an economical alternative for use in decreasing the commercial diets of fish in fish ponds, while simultaneously reducing potential environmental problems. Consumption of macro aggregates can increase nitrogen retention from added feed by $7-13 \%$. In this context, BFT has driven opportunities to use alternative diets.
\end{abstract}

Keywords: Biofloc; C/N ratio; Bioremediation; Sustainable production

\section{Introduction}

Global fish production has grown steadily in the last five decades, with food fish supply increasing at an average annual rate of $3.2 \%$, outpacing world population growth at $1.6 \%$ [1]. Due to rapid intensification in aquaculture, high input of feed and high stocking density create environmental problem. BFT is the retention of waste and its conversion to biofloc as a natural food within the culture system Hargreaves JA [2] also it enables intensification at a relatively reasonable investment and operating cost [3]. The main principle is 


\section{International Journal of Oceanography \& Aquaculture}

to recycle nutrient by maintaining a high carbon/ nitrogen $(\mathrm{C} / \mathrm{N})$ ratio in the water in order to stimulate heterotrophic bacterial growth that converts ammonia into microbial biomass [4]. The microorganisms have two major roles as maintenance of water quality, by the uptake of nitrogen compounds generating "in-situ" microbial protein; and increasing culture feasibility by reducing feed conversion ratio and a decrease of feed costs.

BFT is a real "environmentally friendly system" with a "green" approach. Bacterial supplementations include microbial flocas natural food to improve growth, prevention of pathogen proliferation through competitive exclusion, and immune-stimulation of the immune system of target organisms [5-7]. Carbohydrate addition in extensive shrimp ponds improved the nitrogen retention efficiency and had a positive effect on production [8,9]. In biofloc medium, yeast decreases $\mathrm{pH}$ due to transformation of sugars into lactic acid by the Lactobacillus spp. can, at the same time, avoid the proliferation of pathogens, which has been shown for pathogenic Vibrio species in shrimp aquaculture $[10,11]$.

\section{Overview of Biofloc Technology (BFT)}

According to, BFT was first developed in early 1970s at Ifremer-COP $[12,13]$. The first commercial application is reported in 1988 in Tahiti as well as the Belize Aquaculture farm where much of the expertise for running shrimp biofloc systems was developed [14]. In India, biofloc technology is not yet popular. This technology was first applied in the extensive culture system of $P$. monodon, in Kerala, India [8]. BFT is also applied with success in the hatchery system of freshwater prawn, $M$. rosenbergii also culture of GIFT tilapia has been successfully done in biofloc system as BFT helped to improve optimum growth and improved immune status of GIFT and possibility of utilization of biofloc-based zerowater exchange system to ensure bio security and environmental sustainability in farming and inland saline water farming [15-17].

\section{Microbial Composition in Biofloc System}

Two functional groups of bacteria, namely chemoautotrophic nitrifying bacteria, and heterotrophic ammonia assimilating bacteria prevalent in BFT $[18,19]$. Microbial mats are able to adapt to large fluctuations in dissolved oxygen and $\mathrm{pH}$ and were able to remove and stabilize different organic and inorganic substrates partly due to the mixed autotrophic and heterotrophic communities that co-exist in the substrate matrix [20] (Plate 1). Heterotrophic bacteria remove TAN from water and incorporate it into cellular protein, which can be consumed by the cultured species Lezama-Cervantes $\mathrm{C}$, et al [21]. Additionally, heterotrophic bacteria have a growth rate up to ten times higher than nitrifying bacteria, which results in a much more rapid reduction of TAN levels and increase in microbial biomass [22]. The common range of bacteria in zero exchange intensive ponds is from $10^{7}$ to $10^{8}$ cells $\mathrm{mL}^{-1}[23]$.

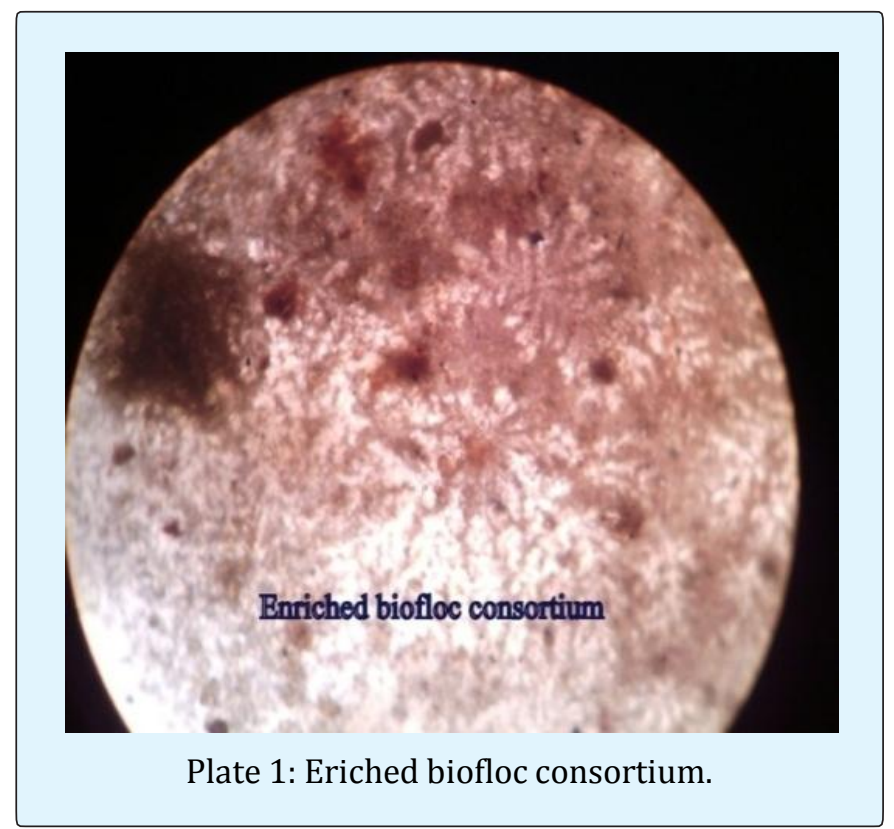

\section{Energy Source for Bacteria and Carbon Addition in Biofloc}

Biofloc or nitrifying colonies of bacteria require incorporation of additional carbon sources into the system to maintain high density because carbohydrates in the system may be insufficient. C:N ratio plays an integral part of BFT systems as the ratio controls the proliferation of heterotrophic bacteria $[24,25]$. It is best to maintain a $\mathrm{C} / \mathrm{N}$ ratio between 10:1 and 20:1 in BFT Luo G, et al [26]. Some of the main sources of carbon that can be used in aquaculture crops are locally available likely glycerol and sodium acetate, sugar, tapioca flour, wheat flour, and molasses etc [27]. As protein is comprised on average of $15.5 \% \mathrm{~N}$, and fish excretes much as $75 \%$ of $\mathrm{N}$ from the feed as $\mathrm{NH}_{4}$ [23], the amount of feed can be inserted along with the calculated $\% \mathrm{~N}$ content of the feed expressed as a decimal, into the equation presented by Avnimelech Y [4] and Hargreaves JA [23] below to calculate the amount of $\mathrm{CH}$ addition needed: $\Delta \mathrm{CH}=\Delta$ Feed $\times \% \mathrm{~N}$ in feed $\times \% \mathrm{~N}$ 


\section{International Journal of Oceanography \& Aquaculture}

excretion $\div 0.05$ The amount of nitrogen needed for the production of new cell material depends on the $\mathrm{C} / \mathrm{N}$ ratio in the microbial biomass which is about 4 Emerenciano $\mathrm{M}$, et al. [28] and also assuming that the added carbohydrate contains $50 \% \mathrm{C}$, the $\mathrm{CH}$ addition needed to reduce total ammonia nitrogen (TAN) concentration by 1

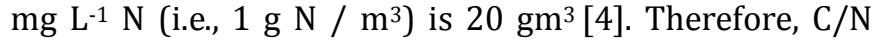
ratio in an aquaculture system can be increased by the addition of cheap carbohydrate source or reduction of protein content in the feed $[4,2]$.

\section{Candidate Fish and Shellfish Species for Biofloc Culture System}

In BFT system, species should be able to tolerate poorer water quality with high solids, as well as obtain nutrition from the biofloc through filter feeding [24]. Shrimp and tilapia are the major species cultured in BFT systems, with Gaudy AF, Jr. Gaudy ET [29] ear-marking tilapia which was the first studied species for the biofloc ponds. Growing shrimp using biofloc technology (BFT) was proposed as a tool to reduce water exchange and minimize the introduction of viral pathogen thorough incoming water Emerenciano $M$, et al [15] made an attempt to evaluate the effectiveness of biofloc technology in larval rearing of the giant freshwater prawn. The authors also investigated the production potential of biofloc based culture systems of Litopenaeus vannamei, Oreochromis mossambicus and Cyprinus carpio var. communis $[9,30,31]$.

\section{Physico-Chemical Parameters of Water in Biofloc System}

Biofloc systems are more efficient when water temperature is between 28 to $30^{\circ} \mathrm{C}$. Nitrifying bacteria can support a range from $8-30^{\circ} \mathrm{C}$ [32]. $\mathrm{pH}<6$ and $>8.5$ usually affects the efficiency of the biofloc components. The concentration of suspended matter in the range of 250 - $450 \mathrm{mg} \mathrm{L}^{-1}$ ensures efficient bacterial activity. In $\mathrm{BFT}$, the $\mathrm{pH}$ level may decrease due to the reduction in the alkalinity level and the increase of dissolved $\mathrm{CO}_{2}$ [33]. Alkalinity should be kept between 100 and $150 \mathrm{mgL}^{-1}$ as $\mathrm{CaCO}_{3}$ by regular additions of sodium bicarbonate. The recommended concentrations of ammonia- nitrogen is $<1.5 \mathrm{mgL}^{-1}$ in cultures with biofloc [34]. Recommended nitrite-nitrogen concentration $<2 \mathrm{mgL}^{-1}$ in cultures with biofloc. One of the techniques used to quantify bioflocs is to measure the total suspended solids (TSS) (Plate. 2) in the water [35].

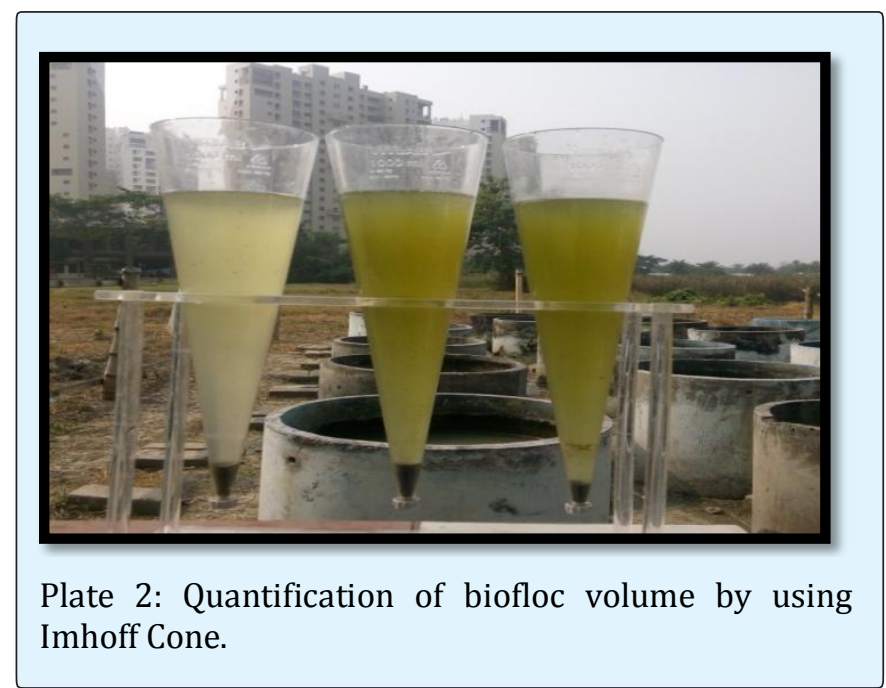

The steady decline in water transparency in BFT ponds likely reflects the progressive formation of bioflocs with the increase of bacteria also suggested that nitrogen uptake by heterotrophic process that likely to dominate BFT system consumes alkalinity half than nitrification (3.57 g alkalinity/g $\mathrm{NH}_{4}{ }^{+}-\mathrm{N}$ ) noticed that increase of nitrogen and phosphorus in biofloc system is due to nitrogen metabolization in presence of suitable carbon reserve in biofloc as which was affected in microbial protein synthesis $[36,18,19,31]$. Biofloc treated systems balancing of total available nitrogen and phosphorus was independent of orthophosphate which never became limited in culture of Cyprinus carpio in neem supplemented biofloc system as this might be due to the fact that microbial flocs favoured mineralization of phosphorus [30] also bioflocs have exerted positive influence in maintaining N:P ratio of water essential for overall productive capacity of aquatic systems [30].

\section{Bioremediation: Biofloc Act as Biocontrol Measure}

Biofloc can be a novel strategy for disease management with perspective of antibiotic, probiotic and prebiotic application. The disruption of quorum sensing, bacterial cell-to-cell communication with small signal molecules [37], has been proposed as a new strategy to control bacterial infections in aquaculture as this cell-to cell communication mechanism regulates the expression of virulence factors [38]. Bioflocs can assimilate pollutants from the water column and provide farmed shrimp with protein during the grow-out period [39]. 


\section{International Journal of Oceanography \& Aquaculture}

In BFT, $\mathrm{pH}$ decrease due to transformation of sugars into lactic acid by the Lactobacillus spp. can, at the same time, avoid the proliferation of pathogens [10]. The probiotic altered the species composition of the Vibrio community [40]. In BFT, probiotic is known to produce communication molecules could in turn interfere with the communication between vibrios and therefore prevent their proliferation. Similar result was found when neem supplemented biofloc was the most effective in controlling bioluminescence pathogenic Vibrio bacteria in Litopenaeus vannamei farming [9].

Water of shrimp tanks fed bioflocs inoculated with Bacillus had an on average 5 times lower Vibrio load when compared to the shrimp tanks fed an artificial feed [41]. An intracellular biodegradable polymer poly- $\beta$ hydroxybutyrate (PHB) and PHB accumulating bacteria have been shown before to protect different aquaculture animals from bacterial infections. PHB might offer a prebiotic advantage for aquaculture. It was observed that the regular addition of carbon to the culture is known to select for polyhydroxyalkanoate (PHA) accumulating bacteria such as Alcaligenes eutrophus, Azotobacter vinelandii, Pseudomonas oleovorans and others that synthesise PHA granules which can reduce of $\mathrm{pH}$, in which antibacterial activity increases with decreasing $\mathrm{pH}$ value and inhibit the growth of pathogenic bacteria by interference on cell membrane structure and membrane permeability, as well as instability of internal protons balance, lowering ATP and depletion of cellular energy [42].

\section{Nutritional Properties of Biofloc}

Found a crude protein content of between 39 and $48 \%$ for biofloc collected from Red tilapia trials of varying stocking density [43]. However, Gaudy AF, Jr. Gaudy ET [29] presented 17.2-27.8 \% protein for biofloc harvested from shrimp culture systems, with Diana A [41] recording $58 \%$, which is testimony of the varying consistency between production environments. Suggested that Biofloc volume did not differ between the media with and without neem supplement, significant difference in the protein content between them indicated superiority of the former in terms of protein and lipid content that was vital nutrients in L. Vannamei farming [9].

The lipid content of 6-7.5 \% found by Gaudy AF, Gaudy ET [29] was within the typical range of 0.5-15\% reported by Avnimelech Y [24]. This high lipid level reported by De Schryver P, et al [43] may be partly explained by the high level of diatoms reportedly found in the biofloc investigated, which can contain lipid levels of up to $25 \%$ [44]. High protein, polyunsaturated fatty acid (PUFA) and lipid content are the most important parameters determining the feasibility of the bio-flocs as feed in aquaculture. Not only the nutritional value of the bio-flocs is important but also other internal compounds may also be beneficial to the aquaculture species.

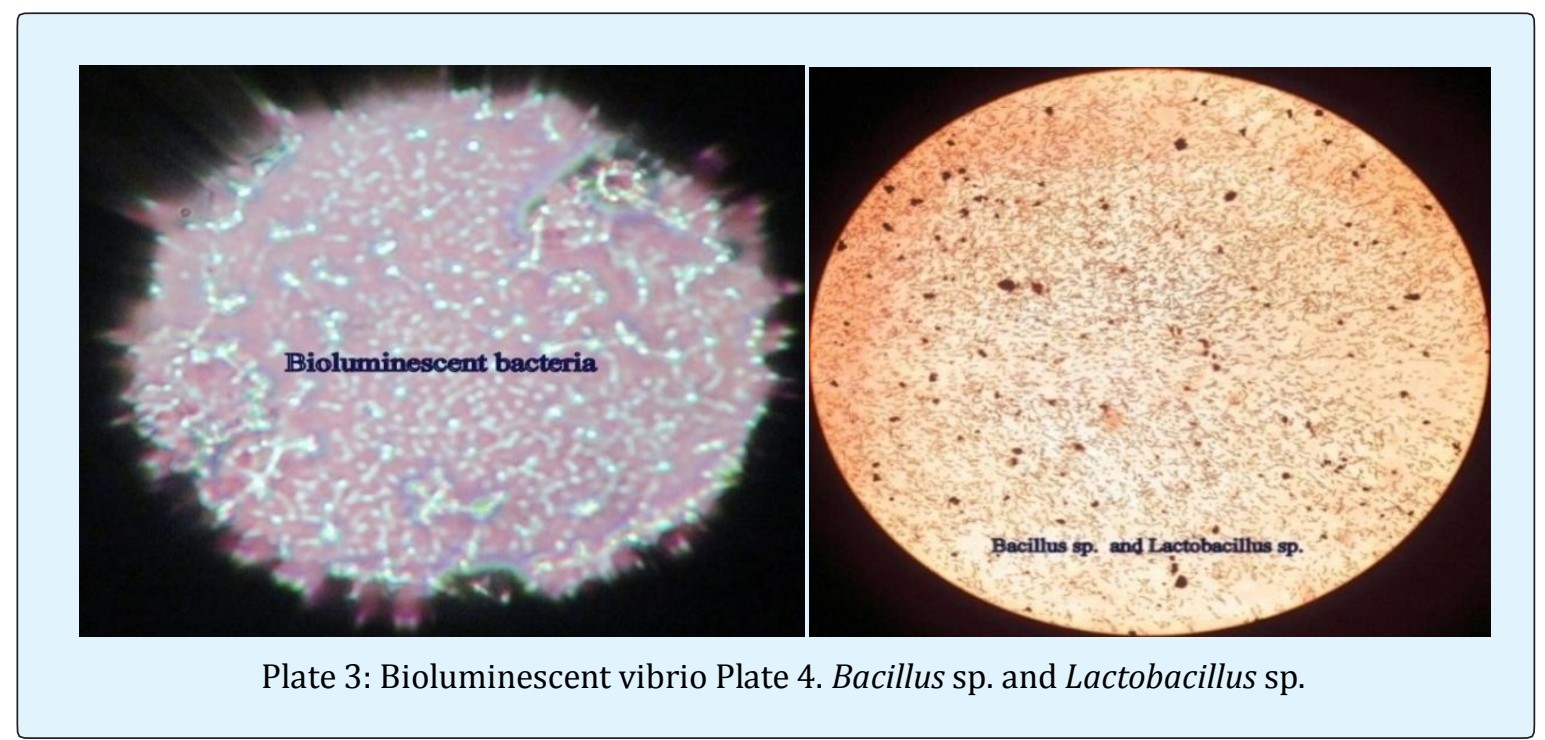




\section{International Journal of Oceanography \& Aquaculture}

\section{Feeding and Growth Response of Culture Species in a Biofloc System}

In -situ utilization of biofloc requires a filter feeding species to harvest the biofloc directly from the water in which it is cultured, and is the major application of BFT in the aquaculture industry today [29]. There are number of ways in which the gain experienced in BFT systems is expressed $[24,9]$. Suggested that shrimp or tilapia in biofloc systems are able to derive $20-30 \%$ of their growth from feeding on this available microbial protein. A study by put forward that the biofloc consumed by tilapia makes up around $50 \%$ of the usual amount of feed which is fed to the fish [45]. It is therefore evident that within BFT systems following the conventional, low-cost, in- situ approach, the administering of pelleted feed is able to be significantly reduced, as the cultured organism is able to feed on the biofloc ad lib [43]. The benefit from the ad lib availability of biofloc in these systems is therefore evident.

Reported that microalgae present in the culture system significantly improved weight gain and FCR of shrimp, thus potentially reducing the feed cost associated with shrimp production [46]. So presence of biofloc can increase growth and decrease FCR which means that shrimp can benefit from the nutritional quality of biofloc [47]. Biofloc media were proved to be highly efficient in reducing the FCR value $(42.95 \%$ and $44.96 \%$ respectively) as compared to the conventional feeding [9]. Biofloc can also improve the performance of supplementary feed both in terms of feed conversion ratio and feed conversion efficiency [31].

\section{Biofloc as Alternative Feed in Aquaculture}

It is important to determine if alternative ingredients derived from biologically treating fish waste, bioflocs (microbial flocs), could be a suitable replacement ingredient in marine shrimp diets. The concept of heterotrophic food web indicates that fish can be fed directly or indirectly on primary producers and also have a chance to feed on bacteria degrading residues present in the pond [45]. Biofloc technology is applicable to both freshwater and seawater systems, both to control water quality and to produce as an additional feed source in situ. The potential feed gain of the application of biofloc technology is estimated to be in the order of $10-20 \%$ [48]. With this, production costs will decline considerably since food represents $40-50 \%$ of the total production costs [49]. The potential of biofloc in supporting the omnivorous carp like Cyprinus carpio L. was established as absolute weight gain was $57.64 \%$ with biofloc alone and was effective in reducing the cost of production as feed conversion efficiency [50].

Production of new biomass in BFT is used as alternative food source [51]. In this view, the nutritional composition of the bioflocs is of uppermost importance to economically produce a healthy, high quality product [52]. Regarding to biofloc meal production, one bottleneck seems to be the large amount of wet biofloc biomass required to produce $1 \mathrm{~kg}$ of dry biofloc meal [45]. The biofloc community has strong potential in reducing the cost of production by cutting down the feed cost and also can improve the environmental health of the culture system with less loading of nitrogenous metabolites and uneaten feed residues [30].

\section{Conclusion}

Biofloc technology is an environmental and sustainable technology used in aquaculture to maintain water quality through converting nitrogenous waste into bacterial proteinaceous biomass after the addition of carbohydrate sources and also can be subsequently consumed by the cultivated aquatic organisms. Although any carbohydrate may be used as a carbon source, sugar cane molasses is more commonly used in fish and shrimp farming. Further studies are required to investigate the impacts of different carbon sources on the microbial community and biofloc formation in super intensive aquaculture environments with zero water exchange. There is also a need to determine the effects of other carbon sources on the performance of shrimp and the maintenance of water quality. Literatures on the growth and environmental performances of BFT in fin fish like tilapia and common carp is lacking from this part of the globe where the above species has tremendous potential in the freshwater farming system. Moreover, comparative studies with variable media composition, variable test fish and with variable feeding regimes under different levels of crude proteins and feeding rate should be addressed by the future researchers.

\section{References}

1. FAO (2014) The State of World Fisheries and Aquaculture- Opportunities and challenges. FAO Fisheries Department E-ISBN 978-92-5-108276-8 Rome. pp: 221.

2. Hargreaves JA (2006) Photosynthetic suspendedgrowth systems in aquaculture. Aquaculture Engineering 34(3): 344-363. 


\section{International Journal of Oceanography \& Aquaculture}

3. Avnimelech Y (2011) Tilapia production using biofloc technology (BFT). In LIPING, FITZSIMMONS. Better science, better fish, better life. Proceedings of the Ninth International Symposium on Tilapia in Aquaculture. United States: AQUAFISH Collaborative Research Support Program 359: 361.

4. Avnimelech Y (1999) C / N ratio as a control element in aquaculture systems. Aquaculture 176(3-4): 227235.

5. El-Haroun ER, Goda A, Chowdhury MAK (2006) Effect of dietary probiotic Biogen ${ }^{(R)}$ supplementation as a growth promoter on growth performance and feed utilization of Nile tilapia Oreochromis niloticus (L.). Aquaculture Research 37(14): 1473-1480.

6. Verschuere L, Rombaut G, Sorgeloos P, Verstraete W (2000) Probiotic bacteria as biological control agents in aquaculture. Microbiology Molecular Biology Reviews 64(4): 655-671.

7. Ganguly S, Paul I, Mukhopadhayay SK (2010) Application and effectiveness of immunostimulants, probiotics, and prebiotics in aquaculture: A review. Israel Journal of Aquaculture-Bamidgeh 62(3): 130138.

8. Hari B, Kurup BM, Varghese JT, Schrama JW, Verdegem MCJ (2004) Effects of carbohydrate addition on production in extensive shrimp culture systems. Aquaculture 241(1-4): 179-194.

9. Mandal A (2017) Environmental amelioration and production potential of biofloc based culture systems of Litopenaeus vannamei, Oreochromis mossambicus and Cyprinus carpio var. communis. Ph.D. Thesis. West Bengal University of Animal and Fishery Sciences. Pp: 327.

10. Ma CW, Cho YS, Oh KH (2009) Removal of pathogenic bacteria and nitrogen by Lactobacillus spp. JK-8 and JK-11. Aquaculture 287: 266-270.

11. Griffith DRW (1995) Microbiology and the role of probiotics in Ecuadorian shrimp hatcheries. In: Larvi'95-Fish \& Shellfish Larviculture Symposium. In: Lavens P, Jarpers E, Roelants I (Eds.), European Aquaculture Society, Special Publication 24, Gent, Belgium, pp: 478.

12. Emerenciano M, Cuzon G, Lopez-Aguiar K, NorenaBarroso E, Mascaro M, et al. (2011) Biofloc meal pellet and plant-based diet as an alternative nutrition for shrimp under limited water exchange systems. CD of abstracts of World Aquaculture Society Meeting 2011, Natal, RN, Brazil.

13. Aquacop (1975) Maturation and spawning in captivity of penaeid shrimp: Penaeus merguiensis de Man Penaeus japonicus Bate Penaeus aztecus Ives Metapenaeus ensis de Hann Penaeus semisulcatus de Haan. Journal of the World Aquaculture Society 6(14): 123-132.

14. Sohier L (1986) Microbiologie applique'e a` l'aquaculture marine intensive. The se Doctorat d'Etat, Universite' Aix-Marseille II Marseille, France, pp: 119.

15. Emerenciano M, Gaxiola G, Cuzon G (2013) Biofloc Technology (BFT): A Review for Aquaculture Application and Animal Food Industry. Biomass NowCultivation and Utilization. Published by INTECH.

16. Saritha T, Kurup BM (2011) Optimization of stocking density in the larviculture of Macrobrachium rosenbergii (de Man ) using the modified static green water system with and without Biofloc Technology, Asia Pacific Aquaculture, 2011- Meeting Abstract, Cochin, India.

17. Haridas H, Verma AK, Rathore G, Prakash C, Sawant PB, et al. (2017) Enhanced growth and immunophysiological response of Genetically Improved Farmed Tilapia in indoor biofloc units at different stocking densities. Aquaculture Research 48(8): 4346-4355.

18. Sonia (2017) Effect of pulsed feeding in GIFT under biofloc using inland saline water growth and survival, physical and immunology parameter. MFSc Thesis. Central Institute of Fisheries Education, Mumbai, pp: 150.

19. Ebeling JM, Timmons MB, Bisogni JJ (2006a) An engineering analysis of the stoichiometry of autotrophic, heterotrophic bacterial control of ammonia-nitrogen in zero-exchange production. In: Rakestraw TT, Douglas LS, Marsh L, Granata L, Correa A, Flick GJ (Eds.), Proceedings of the $6^{\text {th }}$ International Conference on Recirculation Aquaculture. Roanoke, VA, pp: 28-37.

20. Ebeling JM, Timmons MB, Bisogni JJ (2006b) Engineering analysis of the stoichiometry of 


\section{International Journal of Oceanography \& Aquaculture}

photoautotrophic, autotrophic, and heterotrophic removal of ammonia-nitrogen in aquaculture systems. Aquaculture 257(1-4): 346-358.

21. Lezama-Cervantes C, Paniagua-Michel J (2010) Effects of constructed microbial mats on water quality and performance of Litopenaeus vannamei post-larvae. Aquaculture Engineering 42(2): 75-81.

22. Ray AJ, Seaborn G, Leffler JW, Wilde SB, Lawson A, et al. (2010) Characterization of microbial communities in minimal-exchange, intensive aquaculture systems and the effects of suspended solids management. Aquaculture 310 (1-2): 130138.

23. Hargreaves JA (2013) Biofloc production systems for aquaculture. Southern Regional Aquaculture Center SRAC Publication No 4503: 1-12.

24. Avnimelech Y (2012) Biofloc Technology - A Practical Guide Book, 2nd (Edn.), The World Aquaculture Society Baton Rouge Louisiana EUA 34(4): 19-21.

25. Hargreaves JA (2013) Biofloc production systems for aquaculture. Southern Regional Aquaculture Center SRAC Publication No 4503: 1-12.

26. Luo G, Gao Q, Wang C, Liu W, Sun D, et al. (2014) Growth, digestive activity, welfare, and partial costeffectiveness of genetically improved farmed tilapia (Oreochromis niloticus) cultured in a recirculating aquaculture system and an indoor biofloc system. Aquaculture 422-423: 1-7.

27. Asaduzzama M, Wahab MA, Verdegem MCJ, Huque $S$, Salam MA, et al. (2008) C/N ratio control and substrate addition for periphyton development jointly enhance freshwater prawn Macrobrachium rosenbergii production in ponds. Aquaculture 280(14): 117-123.

28. Emerenciano M, Cuzon G, Lopez-Aguiar K, NorenaBarroso E, Mascaro M, et al. (2011) Biofloc meal pellet and plant-based diet as an alternative nutrition for shrimp under limited water exchange systems. CD of abstracts of World Aquaculture Society Meeting 2011, Natal, RN, Brazil.

29. Gaudy AF, Gaudy ET (1980) Microbiology for Environmental Scientists and Engineers. McGraw-Hill, New York, pp: 736.
30. Ekasari J, Zairin M, Putri DU, Nora Putri Sari, Enang Harris Surawidjaja, et al. (2013) Biofloc-based reproductive performance of Nile tilapia Oreochromis niloticus L. broodstock. Aquaculture Research 46(2): 509-512.

31. Dinda R (2015) Neem (Azadirachta indica) supplemented biofloc medium in common carp (Cyprinus carpio, L.) culture: Growth response and environmental health. MFSc. Thesis West Bengal University of Animal and Fishery Sciences pp: 65.

32. Sarkar M (2015) Comparative efficacy of biofloc and feed based common carp (Cyprinus carpio, L.) production system with special reference to environmental health. MFSc Thesis West Bengal University of Animal and Fishery Sciences Kolkata India pp: 56.

33. Gerardi MH (2002) Nitrification and Denitrification in the Activated Sludge Process. John Wiley and Sons, New York.

34. Furtado PS, Poersch LH, Wasielesky W (2011) Effect of calcium hydroxide, carbonate and sodium bicarbonate on water quality and zootechnical performance of shrimp Litopenaeus vannamei reared in bio-flocs technology (BFT) systems. Aquaculture 321(1-2): 130-135.

35. Mallasen M, Valenti WC (2006) Effect of nitrite on larval development of giant river prawn Macrobrachium rosenbergii. Aquaculture 261(4): 1292-1298.

36. Schryver DP, Crab R, Defoirdt T, Boon N, Verstraete W (2008) The basics of bio-flocs technology: the added value for aquaculture. Aquaculture 277(3-4): 125137.

37. Avnimelech Y, Lacher M (1999) Carbon/nitrogen ratio as a control element in aquaculture systems. Aquaculture 176(3-4): 227-235.

38. Defoirdt T, Boon N, Sorgeloos P, Verstraete W, Bossier $P$ (2008) Quorum sensing and quorum quenching in Vibrio harveyi: lessons learned from in vivo work. ISME Journal 2(1): 19-26.

39. Defoirdt T, Boon N, Bossier P, Verstraete W (2004) Disruption of bacterial quorum sensing: an unexplored strategy to fight infections in aquaculture. Aquaculture 240(1-4): 69-88. 


\section{International Journal of Oceanography \& Aquaculture}

40. Valdes CEM, Macias EB, Alvarez-Gonzalez CA, Hernandez CT, Sanchez AJ (2013) Efecto de microorganismos con potencial probiotico en la calidad del agua y el crecimiento de camaron Litopenaeus vannamei (Decapoda: Penaeidae) en cultivo intensivo. Revista de Biologia Tropical 61(3): 1215-1228.

41. Diana A, Alejandra PD, Karla E, Cristina C, Gerard C, et al. (2014) Probiotic effect of FLOC on Vibrios in the pacific white shrimp Litopenaeus Vannamei. Aquaculture 424-425: 215-219.

42. Crab R (2010) Bioflocs technology: an integrated system for the removal of nutrients and simultaneous production of feed in aquaculture. PhD thesis Ghent University, pp: 178.

43. De Schryver P, Sinha AK, Kunwar PS, Baruah K, Verstraete $W$, et al. (2010) Poly- $\beta$-hydroxybutyrate (PHB) increases growth performance and intestinal bacterial range-weighted richness in juvenile European sea bass, Dicentrarchus labrax. Appl Microbiol Biotechnol 86(5): 1535-1541.

44. Salehizadeh H, Van Loosdrecht MCM (2004) Production of polyhydroxy-alkanoates by mixed culture: recent trends and biotechnological importance. Biotechnology Advances 22(3): 261-279.

45. Widanarni, Ekasari J, Maryame S (2012) Evaluation of Biofloc Technology Application on Water Quality and Production Performance of Red Tilapia Oreochromis sp. Cultured at Different Stocking Densities. HAYATI Journal of Biosciences 19(2): 73-80.
46. Shifrin NS, Chisholm SW (1981) Phytoplankton lipids: interspecific differences and effects of nitrate, silicate and light-dark cycles. J Phycol 17(4): 374-384.

47. Avnimelech Y (2007) Feeding with microbial flocs by tilapia in minimal discharge bioflocs technology ponds. Aquaculture 264(1-4): 140-147.

48. Sanchez DR, Fox JM, Gatlin D, Lawrence AL (2012) Dietary effect of squid and fish meals on growth and survival of Pacific white shrimp Litopenaeus vannamei in the presence or absence of phytoplankton in an indoor tank system. Aquaculture Research 43(12): 1880-1890.

49. Xu WJ, Pan LQ (2013) Enhancement of immune response and antioxidant status of Litopenaeus vannamei juvenile in biofloc-based culture tanks manipulating high $\mathrm{C} / \mathrm{N}$ ratio of feed input. Aquaculture 412-413: 117-124.

50. De Schryver P, Crab R, Defoirdt T, Boon N, Verstraete W (2008) The basics of biofocs technology: the added value for aquaculture. Aquaculture 277: 125-137.

51. Craig S, Helfrich LA (2002) Understanding fish nutrition, feeds and feeding. Department of fisheries and wildlife sciences. Virginia Tech 1-6.

52. Avnimelech Y (2006) Bio-filters: the need for an new comprehensive approach. Aquacultural Engineering 34(3): 172-178. 